ARTICLE

\title{
Innovation in the digital era: new labor market and educational changes
}

\author{
Sidney Luiz de Matos Mello ${ }^{a}$ \\ Nicholas Van Erven Ludolf ${ }^{b}$ \\ Osvaldo Luiz Gonçalves Quelhas c \\ Marcelo Jasmim Meiriño ${ }^{d}$
}

\section{Abstract}

The digital era highlights industrial advances, changes in the labor market, and in the educational system. This study investigates these factors through analytical indicators such as the workforce, education, and innovation in Brazil within a global context. It is a qualitative exploratory research that enables a reflection on the relations between the workforce and technological education for the skilled labor. The database used includes documentary data from the literature and data from census surveys in Brazil and abroad. Data indicate that Brazil is significantly delayed in the digital industry, human capital, and research - behind all the other BRICS countries (Russia, India, China and South Africa) in terms of innovation. About 11 million people aged 15-29 are not working and are not enrolled in high school, college, technical course, or vocational qualification. The number of students aged 15 to 19 years old attending technical courses is still around $9 \%$. The network of national technical institutes is key for the rapid recomposition of the skilled labor with regard to industry. The Brazilian economy needs to grow to strengthen both the digital industry and research. Public policies need to heed the advice regarding the link between technical education and industry. This is equally important for the success of the Brazilian Agenda for Industry 4.0.

Keywords: Digital transformation. Workforce. Technological education. BRICS.

\footnotetext{
a Universidade Federal Fluminense, Niterói, RJ, Brasil/Global Institute for Advanced Studies, NYC, USA.

b Universidade Federal Fluminense, Niterói, RJ, Brasil.

c Universidade Federal Fluminense, Niterói, RJ, Brasil.

d Universidade Federal Fluminense, Niterói, RJ, Brasil.
} 


\section{Introduction}

Innovation and technology have presented ways for people to produce more with fewer resources. The adoption of new technologies is seen as a strategy to increase product quality and make manufacturing more efficient (TORTORELLA; FETTERMANN, 2017). History has shown that true revolutions can occur when scientific and technological knowledge unleash new forms of production and bring about changes in social and economic relations (TAALBI, 2017).

The first industrial revolution occurred in the eighteenth century with the invention of the steam engine and the development of railroads. The second industrial revolution, from the end of the nineteenth century to the mid-twentieth century, enabled mass production. With the advent of electricity, assembly lines came into being. The third industrial revolution, which started during the early $1960 \mathrm{~s}$, became known as the computer era, with the development of semiconductors, personal computers, and the internet.

Now, the digital era is emerging as the fourth industrial revolution, based on digital technologies, the internet of things (IoT), artificial intelligence (AI) and machine learning. These new technologies have contemporary features such as connected machines, intelligent products and systems, and interrelated solutions (SJÖDIN et al., 2018). Advances in information and communication technologies (ICT) can enable intelligent and flexible production processes and, on the other hand, reshape educational systems (GOMES et al., 2019). Some people have predicted (MCAFEE; BRYNJOLFSSON, 2014) that we are experiencing unprecedented, large-scale and accelerated transformations in the way we live, produce, work, and interact.

One aspect of technological innovation is robots integrated with so-called cyberphysical systems, which combine various factors such as digital, physical, and biological technologies. Many parts of the world are already facing a major technological revolution, in which new jobs and advanced education are at the vanguard. In this respect, Chiappe and Rodríguez (2017) warn of the need to critically analyze education, raising questions about creating schools suitable for the 21 st century.

The digital industry should increase production and create new jobs. However, these jobs may not be suitable for all, leading to greater social inequality, and perhaps, a new type of proletariat as stated in Dyer-Witheford (2015). Countries with a late industrial development and low educational levels such as Brazil are struggling. They are not only once again behind in terms of global development, but they 
face deepening domestic, economic, and social crises, along with their historical economic inequalities in relation to countries that are already in the digital age.

There is a vast amount of recent literature that focuses on the advances due to digital transformations, but also on their positive and negative aspects (NAMBISAN; WRIGHT; FELDMAN, 2019). Previous studies cover one or two topics in depth within the context of innovation (LEE; KANG, 2018). Instead, this study looks at innovation in a broader sense in order to understand to what extent the workforce and technical education interact in terms of supplying the market with skilled labor. Firstly, it describes the study method and the database. Then, there are sections on trends in innovation and digital technologies, workforce in the labor market and educational changes, allowing an analysis of the current situation, as well as the expected progress in digital transformations in the near future. The last section deals with Brazil's performance in terms of innovation, which is at the center of our discussion and analysis, as we examine the country's educational needs and position, as a large economy among BRICS countries, in terms of the digital industry.

\section{Study methods and data}

The subject of innovation deserves ongoing analysis and updates as it is changing all the time. This is a qualitative exploratory study (REITER, 2017). The database includes documentary data from the literature, quantitative data from census surveys, and observations, focusing on innovation, workforce, and education in Brazil and abroad. Therefore, our sources of evidence are data analysis, documents in the public domain, and results of census data and interviews. The objective is to provide insights into the problem or to suggest ways of developing ideas or hypotheses for potential quantitative research.

The steps in the study are as follows: (1) Context analysis - previous papers, census surveys, and limitations; (2) Research question-investigate the demand for qualified labor with technical skills in Brazil, within the current situation of unemployment and an increased network of technological institutes; (3) Objective - What is the status of the workforce in Brazil and to what extent does the federal network of technological and vocational education meet the needs of qualifications for those working in the digital industry?; (4) Discussion and results-Comprehensive analysis of all information, including a comparison of Brazil's situation in relation to other BRICS countries and the potential impact on public policies.

The Brazilian Institute of Geography and Statistics (IBGE), through the National Continuous Household Sample Survey (2012-2018 PNAD) (AGÊNCIA IBGE, 
2019), has provided the quarterly fluctuations and the short, medium, and long-term evolution of the workforce, together with other necessary information needed to study the socioeconomic development of the country. The World Bank, through Silva et al. (2015), has provided an overview of a survey of jobs skills and the job agenda in Brazil. The World Economic Forum (INSIGHT REPORT, 2018) and the McKinsey Global Institute (2017) have provided an overview of the job situation around the world.

A survey coordinated by the Brazilian Confederation of Industry (CNI) and the Brazilian Micro and Small Business Support Service (Sebrae) between 2011 and 2016 (Confederação Nacional da Indústria/Desempenho do Brasil no índice global de inovação 2011-2016) has made available data on Brazil's Global Innovation Index (GII), based on The Global Innovation Index 2016 framework designed by Dutta, Lanvin e Wunsch-Vincent (2016) (Cornell University, INSEAD, and WIPO, 2016). The World Digital Competitiveness Ranking 2018, carried out by the IMD (Swiss Business School), has also provided a comparison on performance related to innovation in different countries, with a particular emphasis on BRICS countries (IMD, 2018).

The National Institute of Educational Studies and Research Anísio Teixeira (INEP) has just released the statistics of the 2018 School Census, carried out between 2014 and 2018 (INEP, 2018). This provides an overview of the educational situation in Brazil through public and private education networks. In addition, The Organization for Economic Cooperation and Development (OECD) has made available a document entitled "Education at a Glance" (OECD, 2018) with educational indicators positioning Brazil in terms of other OECD member countries.

\section{Trends in innovation and digital technologies}

Malerba (2006) has shown the progress in industrialization through innovation, focusing on knowledge, people, demand, networks, institutions, and coevolution. Technological innovations have driven transformation across industry, economic relations, and behavior as remarked in Schwab (2016). Physical technological innovations include stand-alone vehicles, 3D printing, advanced robotics and new materials. In the digital category, there is the IoT, which connects things and products through platforms and technologies. Blockchain is yet another feature in this category, which operates as an accounting, encrypted, programmable, and secure book capable of recording financial transactions made with digital coins. In the biological category, the main trends in innovation are in the fields of genetics and synthetic biology.

In 2013, according to the online magazine Business Insider, Cisco Systems, Inc. has predicted that 50 billion devices will be connected to the internet by 2020 . 
However, a separate analysis from Morgan Stanley said that this number could actually be as high as 75 billion, claiming that there were 200 unique consumer devices or pieces of equipment that could be connected to the internet that have not yet been linked. No matter what the correct amount, devices connected to the internet will flood the market. The IoT allows us to get correct information at the right time in order to make decisions. Cloud computing ensures that companies extract and analyze information that directly affects their production line and services. Augmented and virtual reality data, coupled with customer feedback, can provide research and development advantages, giving consumers the things they demand together with speed, all at a low cost. AI is all around us - in cars that drive alone, virtual assistant drones and translation software. AI allows for exponential progress, boosted by increased processing capacity and broad data access.

Factories that interconnect machines and people in real time, allowing product customization and the creation of better, faster and more efficient operating models, are now known as "Industry 4.0" - many have employed it as synonym for the fourth industrial revolution. The term originated in the German government's high-tech strategic project (KAGERMANN; WAHLSER; HELBIG, 2013) with the intention of promoting "Intelligent Factories."

Marcelo Blois, director of GE's Digital Innovation, says that industry in the digital era allows machines to see, hear, feel, and send data over the internet in real time, providing more efficient operations and better services (GE REPORTS, 2019). Connectivity and data analysis increase productivity in various operational sectors. For example: (1) GE Water plants carry out data analysis using IoT platforms to deliver direct results $-12 \%$ reduction in energy consumption and up to $8 \%$ in water loss, plus a gain of at least $10 \%$ in average production; and (2) Paraná's railways in Brazil have a locomotive with a very high load capacity - two of these can replace three to five machines with three axles. It is the first locomotive to leave the GE factory in Brazil with an autopilot and sensors that monitor the components of the locomotive for any sign of a problem in real time. This optimizes maintenance work, thus increasing security.

These revolutionary industries are modifying the entire productive system, employing advanced technologies, and empowering the workforce. They are leading the way in all stages of the production, marketing, and management of the companies involved in the trade of goods. More accurate instruments and the introduction of robots have altered the way of organizing the industry, making it possible to increase production and potential profits, thereby reducing labor costs, as well as reducing the time taken to generate the final product. 


\section{Workforce in the new labor market}

The McKinsey Global Institute (2017) has produced scenarios in terms of jobs which suggest that by 2030, 75 million to 375 million workers ( 3 to 14 percent of the global workforce) will need to switch occupational categories. All workers will need to adapt as their occupations will evolve alongside machines. Some of that adaptation will require a higher educational attainment or spending more time on activities that require social and emotional skills, creativity, high-level cognitive capabilities, and other skills that are relatively hard to automate.

The World Economic Forum - Future of Jobs Report 2018 has revealed an estimated decline of up to 0.98 million jobs, but a gain of 1.74 million jobs in the near future. According to their report, 75 million jobs may be displaced by a shift in the division of labor between humans and machines, while 133 million new roles may emerge from a new division of labor between humans, machines, and algorithms.

Almost 75 million young people are officially unemployed across the world. In Brazil, 12 percent of the workforce is unemployed; this equates to about 12 million people (Pesquisa Nacional por Amostra de Domicílio de 2012 a 2018 do IBGE). In addition, there are 13 million people who work less than they could or would like to work but have not looked for a job or were not able to start. We tend to focus our attention on the unemployed and less on those who are underemployed or inactive.

Significant challenges lie ahead for Brazil's policy and business leaders. The future agenda as regards work in Brazil should sharpen the focus on skills and training, strengthen the link between education and employment, provide support for workers through their transitions, improve the flexibility and mobility of labor markets and, of course, maintain robust economic growth to support the creation of jobs. Without an upgrade in skills, the disparity could become twice as severe in the next decade, resulting in a loss of productivity and rising inequality. Upgrading skills on a large scale will require coordination between parents, educators, governments, employers, and employees, with a keen focus on those individuals with lower skills.

It is expected that computer-controlled and automated production will have a severe impact on the labor market, as shown in Figure 1. The McKinsey Global Institute analysis (2017) has estimated that between almost zero and 30 percent of the hours worked globally could be automated by 2030 , depending on the speed of adopting the process of automation and the current technological capability. However, there is no clue as to how many jobs will actually be lost or gained 
in the face of technological progress (WINICK, 2018). While the balance of jobs is not quite clear, researchers are already studying new economic models, forecasting financial compensation in case of job loss or rising unemployment. Models involve the reduction of the length of the working day and measures such as social support, as the State would pay a minimum income to the citizen.

Figure 1 - Impact of automation as regards countries with different income levels, demographics, and industry structures according to the McKinsey Global Institute workforce research (2017). The graphic has been modified from the original showing fewer countries, in particular in a lower range of displacement such as BRICS countries and in a higher range such as the US, Europe and South Korea. The results differ significantly by country, reflecting the activities currently performed by workers and their rates of pay. The range in BRICS countries varies from 9 percent in India to 17 percent in Russia, while the range in the US, Central European countries and South Korea varies from 20 in the UK to 25 in South Korea

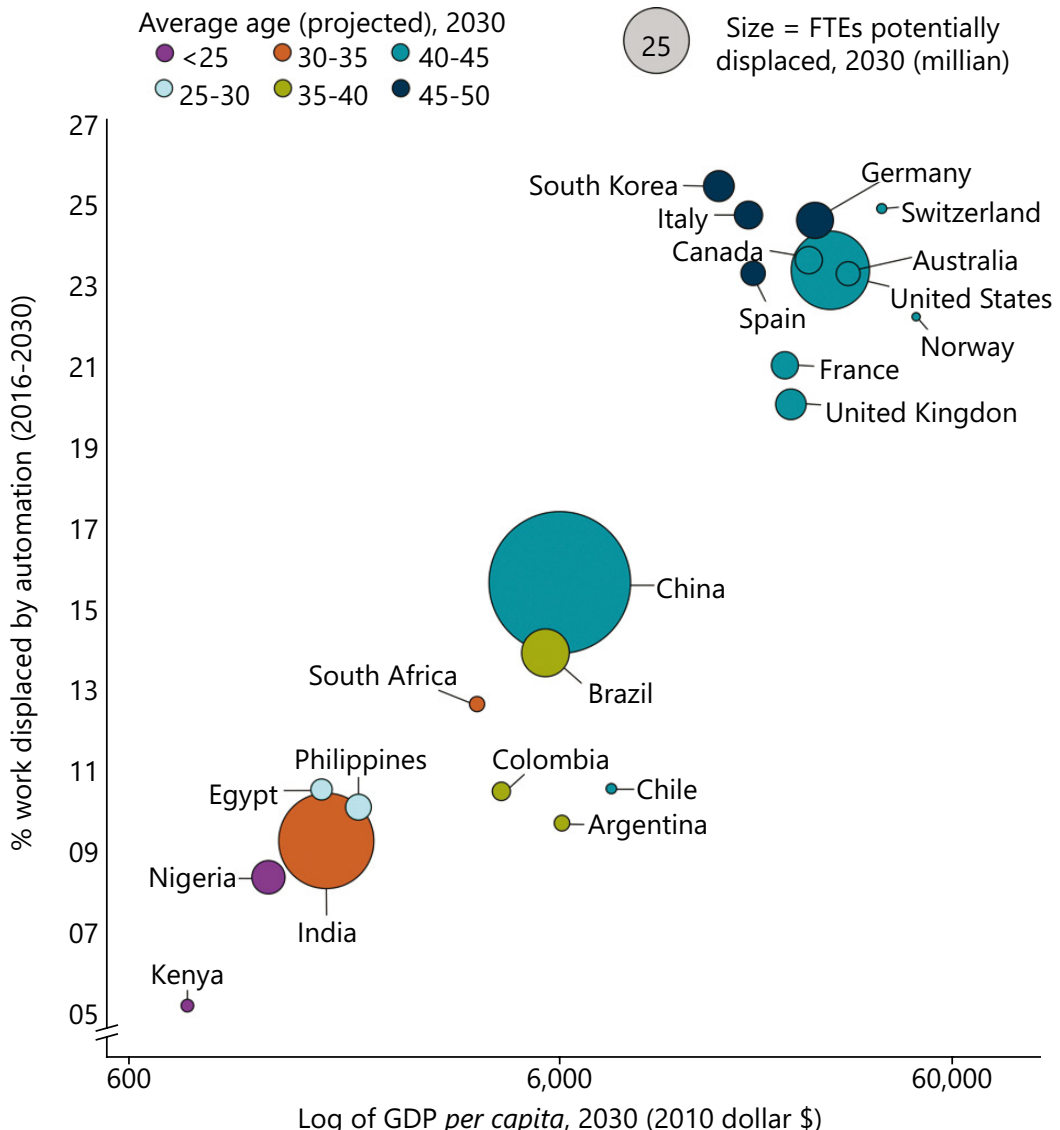

Source: McKinsey Global Institute workforce research (2017). 
"There is always much progress and new risks in the job market. So, worries are justified, but to say there will be a lack of work is scaremongering," says Enzo Weber, a researcher at the German institute, IAB. During the industrial revolution in the eighteenth century, there was a large-scale dismissal as a result of the new technologies in the processing of textiles and agriculture; machines took on certain jobs, but there were increased opportunities for specialized professions.

Consequently, Industry 4.0 should repeat such a trend, maximizing a high level of education and specialized labor. Therefore, education systems are changing around the world, but not so much in underdeveloped nations where the level of investments is low and where there is a lack of efficiency and planning for the future. The challenge is how fast the students and the educators can adapt to the teaching, learning, and assessment methods.

\section{Educational changes}

Education in the future should provide students with the skills they need to succeed, as well as with the emotional intelligence needed to work in groups and with different relationships. Creativity, critical thinking, communication, and collaboration are concepts that should feature in every curriculum, along with language and numeracy. Investigative skills and problem-solving are essential for developing advanced knowledge and confidence. Education needs to provide students with transferable skills that will empower them in a rapidly changing world, but not with prescribed content as past relevance. Robinson and Aronica (2016) argue for an end to our outmoded industrial educational system and propose an organic approach that draws on today's unprecedented technological and professional resources in order to engage all students, develop their love of learning, and enable them to face the real challenges of the twenty-first century.

The new generation of students is entirely engaged in the online environment with access to mobile devices, which makes learning much less centralized. Traditional classroom-based lessons are often considered monotonous and unproductive, giving way to a more dynamic and engaging methodology that ensures student interest. Therefore, there is a consensus that educational institutions that fail to follow this educational revolution will find themselves in serious danger of being trapped in the past by following a teaching methodology that no longer meets the needs of students. 
Access to information has become popular and has made the structure of teaching more democratic and less dependent on the physical environment of the school. Open distance learning (ODL) is an example of the educational revolution enabled by new technologies. It profoundly alters traditional classroom dynamics, as one can study, consult, and even interact with teachers anywhere, anytime. Migrating data to the internet allows for the creation of online portals that can be easily accessed by anyone, reducing costs, logistical difficulties, physical distances, and time conflicts, thereby providing access to many more people.

Above all, the world of education needs a totally new pedagogical approach, even though the challenges are still the same for students wanting to access higher education and the qualified digital labor market. Over the last ten years, education in Brazil has seen some improvements, but numbers are weak in comparison with other nations (OECD, 2018). These numbers are important, but professional and vocational courses, as well as technological institutes, need a better plan for the future.

Created in 2011 by the Ministry of Education (MEC), the National Program for Access to Technical Education and Employment (Pronatec) has raised expectations for the levels to be achieved by Brazilian high school students and for unemployed citizens who have proof of their past profession so that they can achieve new opportunities in their professional life (OLIVEIRA; FERREIRA; SILVA, 2019). The program has offered free vocational and technological courses to youths and adults on a low income. The courses offered by Pronatec have worked in partnership with the federal, state, and municipal networks of professional and technological education, the National Learning Service (Apprenticeship) that is linked to industries and commerce, and private networks as well. Educational authorities announced that Pronatec would offer 12 million vacancies by 2019. However, between 2011 and 2014, the program offered 8.1 million enrollments at a cost of about US $\$ 4$ billion. Nevertheless, the 3 million enrollments offered in 2014 plummeted to 1.2 million in 2015. Apparently, the program has followed a political rather than an educational agenda and may be stopped in the near future. Among the problems that have been highlighted in the Pronatec program are the lack of quality when assessing the courses, the lack of a true link with industry, inadequate facilities, insufficient teachers, and a lack of rigorous control of the application of resources. Despite the fact that the evaluation of Pronatec has been deemed a failure, a well-conducted and monitored program could be successful and attractive to students who want to work and enter the job market quickly (BRASIL, 2018a). 
There has been an increase of 63.0\% over nine years (2008-2016) in high school students who take regular technological degree courses according to the 2016 Census of the National Institute of Educational Studies and Research Anísio Teixeira (INEP). According to this survey, the number of young people taking these courses increased from 1.1 million to 1.8 million. Despite this improvement, the country still has a long way to go. Data from the OECD show that the average number of students aged 15-17 who study at high school or follow a technical course in 34 developed countries is $35.0 \%$, while in Brazil it is only $9.0 \%$.

In 2017, Brazil had 296 public and 2,152 private Higher Education Institutions (HEIs), representing $87.9 \%$ of the network. Of the public ones, $41.9 \%$ are state, $36.8 \%$ are federal and $21.3 \%$ are municipal. Almost three-fifths of the federal HEIs are universities and $36.7 \%$ are Federal Institutes of Education, Science, and Technology (IFs) and Federal Centers for Technological Education (CEFETS). From a total of 8.2 million students enrolled in higher education, 534,935 students $(6.5 \%)$ attended the presential technological graduation and 464,354 students $(5.6 \%)$ took part in distance learning with courses lasting two or three years.

These figures fully justify a massive investment in strengthening technical and vocational courses and institutes. From the 3.2 million Brazilians who are aged 19 , only 2 million have completed high school, representing $63.5 \%$ of the total number (Pesquisa Nacional por Amostra de Domicílio de 2012 a 2018 do IBGEAGÊNCIA IBGE, 2019). Of the total number that did not finish high school, $62 \%$ are no longer in school, and $55.0 \%$ of these young people have stopped studying in elementary school. In 2017, Brazil had 48.5 million people aged 15-29, but 11 million of them were not working and were neither enrolled in high school/ college, nor in a technical or vocational course.

Although Brazil has seen a growth of $71.0 \%$ in the number of students attending technical schools over the last decade, only $9.0 \%$ of 15 - to 19 -year-olds opt for this training model. This presents a huge discrepancy when compared to Germany $(53.0 \%)$, the United States $(60.0 \%)$, South Korea $(65.0 \%)$ or even our neighbor Argentina (34.0\%), according to OECD data. South Korea has been able to show how the highly valued educational model of technical education can make a difference for a nation. The per capita income of Koreans, which was one-third of that of Brazilians in the 1960s, is now three times higher.

The Federal Network of Professional, Scientific and Technological Education (Figure 2), which mainly includes the IFs and Federal CEFETS are key to 
developing skills for the new economies and industries. This network encompasses all states offering qualifications and vocational courses, integrated high school, higher education, and technology courses and undergraduate degrees. Yet, Magalhães and Castioni (2019) have highlighted the fact that the creation of the Federal Technological Institutes has resulted in universities producing more intellectual capital rather than in improving socioeconomic development from economic assets. This is entirely the opposite of countries such as Germany and Switzerland, where students learn content related to the demands of real life, that is, up-to-date information as part of a technological society - where there are smartphones, tablets, and social networks - in order to enable innovation in society. Brazil has difficulty understanding the need for this change in its educational structure, especially in high school, as shown by the World Bank report (SILVA; ALMEIDA; STROKOVA 2015).

Figure 2 - The Federal Network of Professional, Scientific and Technological Education is an important framework for accessing vocational and technological education. There are already more than 661 units around the country linked to 38 Federal Institutes, 2 Federal Centers for Technological Education (CEFETs), the Federal Technological University of Paraná (UTFPR), 22 technical schools linked to federal universities, and the Pedro II College

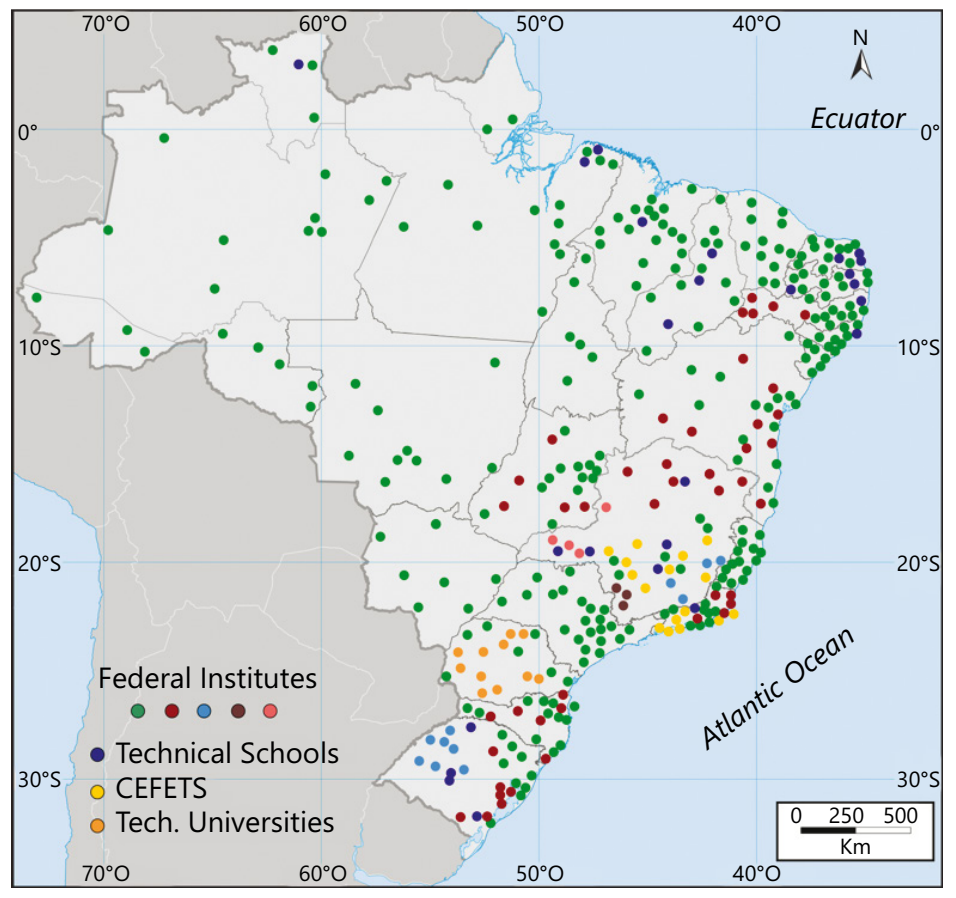

Source: By the authors. Adapted from source portal.mec.gov.br (2019) 
Different parts of Brazilian industry need to fill gaps that have to be occupied by highly qualified technicians. Within an organization, engineers coordinate various technicians, assistant technicians, and so on. Each has specific responsibilities and expertise, making them different and unique inside each corporation. New processes, machines and equipment demand professionals with advanced knowledge and skills.

Technical training needs to be understood by all the people involved in the process - this is a fundamental part of the development of a national industry. Entrepreneurs need to understand how to better benefit from technical professionals and value their contribution. In turn, young people will look to technical education for their professional benefits, thus creating a worthy and necessary circle of development for the country.

\section{Brazil must catch up with the digital future: discussion and analysis}

Apparently, Brazil is ranked the worst in innovation among the BRICS countries, according to research by the National Confederation of Industry (CNI) and the Sebrae entitled Brazil's Performance in GII (2011-2016). This index captures the multiple facets of innovation and is calculated from a large number of areas such as institutions, creative products, knowledge products and technology, infrastructure, business and market solutions, and human capital and research.

Brazil is in 69th position in the survey conducted among 128 countries. China appears 25th in the ranking, followed by Russia (43rd), South Africa (54th) and India (66th). Figure 3 displays the scores for the BRICS countries in the seven GII pillars. According to the innovation landscape, Brazil has shifted from optimism to concern in the last six years. China shows an outstanding position in products related to innovation. In addition, the GII shows that Brazil would need to increase its investments in innovation by $60.0 \%$, in relation to financial and human resources, to reach the same index as Switzerland, which leads the ranking.

Brazil has also been analyzed among 63 countries in the World Digital Competitiveness Ranking 2018 done by the IMD (Swiss Business School). Reading between the lines, the report demonstrates that the country needs to raise its educational standards and solve numerous barriers to become a competitive digital nation. The study was based on fifty variables grouped into three basic 
concepts: knowledge, technology and future-readiness. Various factors were evaluated, such as the regulatory environment, the quality of education, the capacity to generate scientific and technological knowledge, the telecommunications infrastructure, research, and development and innovation, as well as cooperation practices between companies, academia, and governments.

As for the regulatory environment and the availability of capital to finance developments in technology and the telecommunications infrastructure, Brazil has remained below the desired level. Bureaucracy and system complexities are extreme weaknesses, along with the fact that the banking system is concerned with financing short-term goals, and there is little availability of venture capital to fund research and development. Not surprisingly, it is difficult to exploit the advantages of digital transformation in generating new business, as well as to improve business management and public administration, probably because of the low level of digital security and cooperation between the public and private spheres.

Figure 3 - Synthesis of innovation performance among BRICS countries, originally extracted from a publication by the Confederação Nacional da Indústria, Brazil's Performance in Global Innovation Index - GII (CNI, 2016). Brazil, Russia, India, China and South Africa score in the seven GII pillars. China outperforms the other BRICS countries in almost every pillar, especially in terms of innovation products. Brazil lacks creative products, human resources, research and sophistication in both business and markets

Institutions

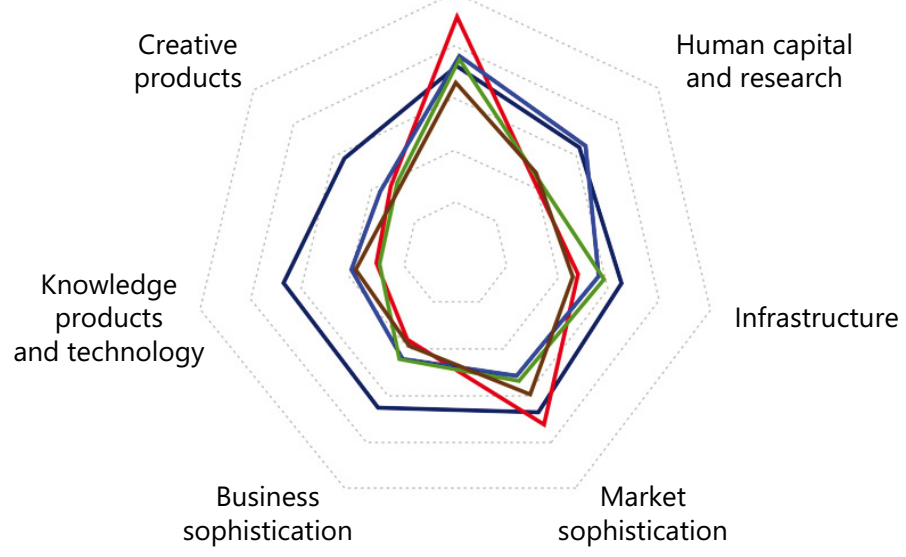

Brazil China Russia South Africa India

Source: Confederação Nacional da Indústria, Brazil's Performance in Global Innovation Index - GII (CNI, 2016). 
Brazil was found to be very weak in terms of knowledge, revealing not only a low level of technological programs in education, but also serious deficiencies in the quality of basic and higher education. Despite being in 10th position in terms of countries with the highest public investment in education (6.2\% of GDP in 2016), Brazil is only 57th as regards its percentage of graduates, with only $16.6 \%$ of the population aged 25-34 with diplomas at a higher level.

Investment in technical education has already been tested and approved by powerful countries and is key for success in the digital industry era. Brazil looks like it might miss this wave, as shown by the PNAD 2014 (IBGE, 2015) interview and survey (Figure 4). From a total of 158 million Brazilians aged 15 years and older who were interviewed about attending a professional course leading to a qualification, only 3.4 million (2.2\%) attended technical high school. However, 40.2 million people said they were interested in this type of education. Among the reasons given for not having taken a professional course was the difficulty reconciling work with domestic activities, cited by $34.4 \%$ of people. In addition, $26.8 \%$ said they could not afford the course and $20.8 \%$ reported that there was no the desired course or vacancy in the place where they lived.

There is, in fact, an enormous potential for the connection between technological education and the digital industry, particularly in the current situation of high unemployment. Technical schools and institutes have to be closer to the models followed by industry than to those followed by universities in order to generate skilled labor. Nowadays, only $25 \%$ of students who graduate from undergraduate technical courses in Brazil end up working in occupations that require such types of training. The courses offered are not quite in tune with the job market and this demotivates students, forcing them to take traditional university degrees that are still out of touch with industry.

As every cloud has a silver lining, the Ministry of Science, Technology, Innovation and Communications (MCTIC) has recently launched the Brazilian Digital Transformation Strategy E-Digital 2018 (BRASIL, 2018b). This is a public policy geared toward digital transformation in the economy's productive sectors. It aims to build capacity in the modern era, as well as to be a service provider and rights guarantor. In March this year, The Ministry of Industry, Foreign Trade, and Services (MDIC), in partnership with the Brazilian Agency for Industrial Development (ABDI) headed the initiative of the Brazilian Agenda for Industry 4.0. The set of measures foreseen in the agenda is directed in particular toward small and medium industries. Among the actions planned are the diffusion of the new Industry 4.0 concept itself, the availability of more affordable credit lines so that industries of all sizes can invest in the adoption or generation of new technologies, a zero rate for the importation of robots, professional training, 
and many other features. In total, about US\$ 2.5 billion will be invested in the entire project with the aim of providing comprehensive support to the Brazilian entrepreneur who wants to follow the technological transformations that are already available around the world.

Figure 4 - The PNAD 2014 (IBGE, 2015) interviewed 158 million young people 15 years old and older on the interest in professional qualification courses. Only 3.4 million (2.2\%) attended technical high school and $\mathbf{4 0 . 2}$ million people said they were interested in this type of education, although different reasons have ruled out such possibility

Professional qualification Course

(Brazilians over 14 years Household Sample Survey, PNDA 2014)

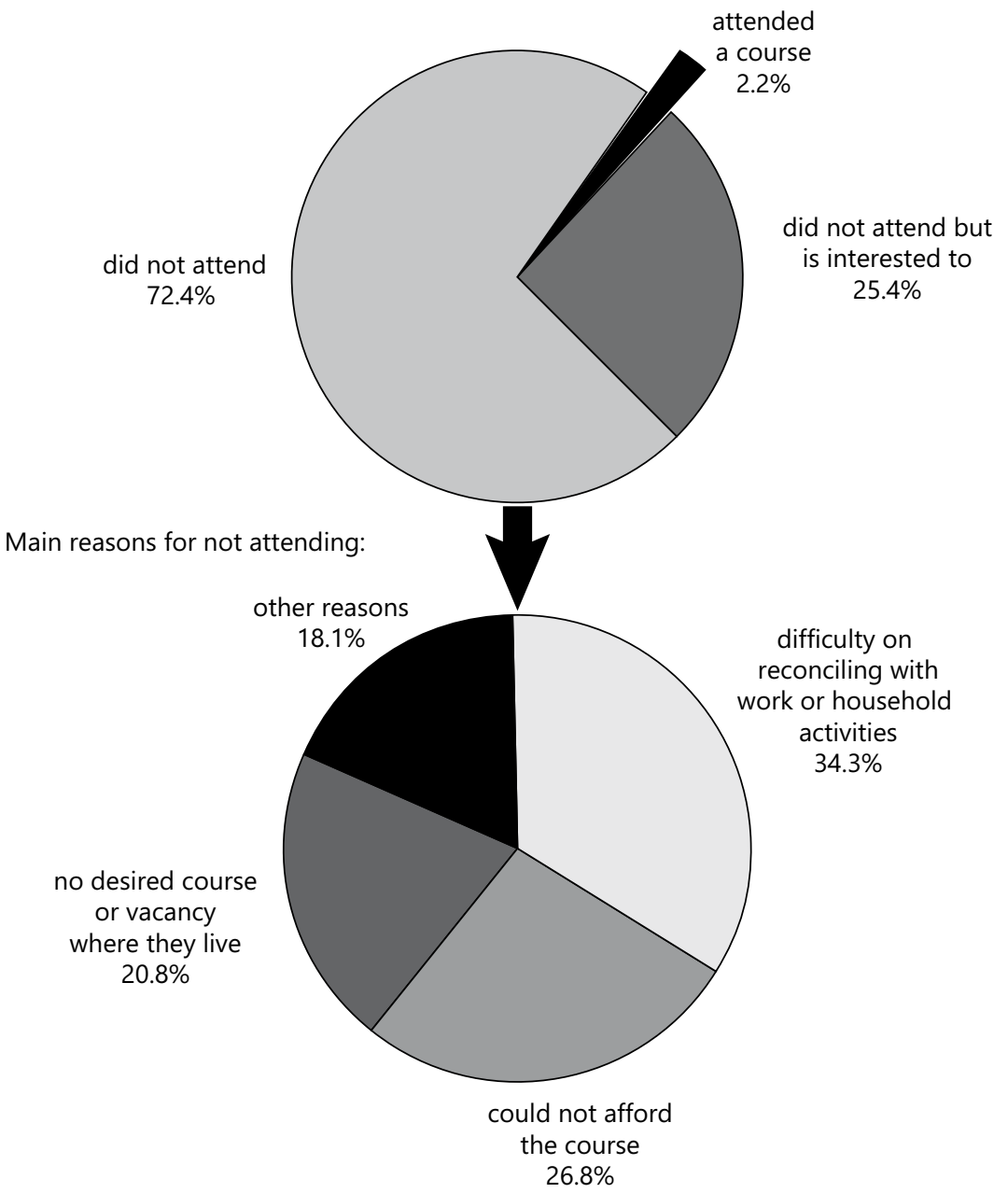

Source: Agência IBGE. Pesquisa Nacional por Amostra de Domicílios - PNAD: síntese de indicadores (PNAD 2012-2018). 
Of course, there is a lot to be done to spark innovation within academia, industry and the government in Brazil. The exposed weaknesses demonstrate that the challenges experienced by the country are not only human, institutional and political, but cultural, since there is a need for the country to evolve socially so it can make advances in technological realities brought about by innovation. The E-Digital policy and Agenda for Industry 4.0 should be well connected to both society and the country as a whole. There is still a struggle to overcome the political, social and economic crises that started in 2014 as a result of the gradual decline in national revenue from commodities.

\section{Conclusions}

The contribution in this work is comprehensive and addresses Brazil's situation as regards the digital industry and the educational qualifications needed for work. It also serves as a point of reference for public policies. The research strategy allows us to survey and analyze documentary and census data on innovation performance in industry, workforce and education in Brazil and abroad.

The results of the data analysis indicate that Brazil is not quite ready for the digital industry. In addition, the country is facing an economic recession with a high level of unemployment to the tune of $12.4 \%$ (13 million people). Brazil has figured at the bottom in different rankings as regards innovation performance, behind all BRICS countries in many indicators.

Low levels of schooling are generally associated with high levels of income inequality. Brazil has one of the most significant numbers of adults who have not completed high school and one of the highest rates of income inequality among OECD member and partner countries. Enrollment rates drop dramatically after 14 years of age: only $69.0 \%$ of the population between 15 and 19 years and $29.0 \%$ of the population between 20 and 24 years attend an educational institution.

There seems to be an obvious disconnect between education and industry, especially in high school and technological higher education, discouraging students from advanced technical development. The technological education network in Brazil is extensive and has the potential to contribute not only to training younger people, but to rebuilding a more qualified workforce. In times of high unemployment, this may be important as regards public policy. So, a public policy is needed to strengthen the training of young people in technological education in high school and college. This is essential due to the much-needed manual training in the new industries and also because of the current level of unemployment in Brazil and the number of people wishing to relocate. 
Brazil needs to accelerate economic development in tandem with industrial innovation and education. The analyzed data show the country's delay in innovation in the wider picture, with low levels of knowledge, technology and future-readiness. To reverse such a poor performance, it is recommended to strengthen policies regarding innovation so that public investments leverage private ones, there is greater cooperation between companies and universities, and there is more encouragement of internationalization and entrepreneurship.

If Brazil wants to become a developed and exporting industrial nation, it needs to build strong networks in science, technology and education, together with better universities and technical schools, to respond to the call of the digital era. The country urgently needs to update its educational model, including not only programs and disciplines regarding new technologies, but also new skills required for the professional of the future. It is crucial that the private and public sectors cooperate, leading efforts and commitments to innovate in all aspects. There are many good examples of innovative models and companies. These examples must become part of a dominant business model and of a culture of transformation in both the technological and behavioral dimensions of our society.

As regards future work, this current research quantifies Brazil's performance in innovation and follows the progress of a network of technological education systems linked to industries. The topic should be expanded by exploring and highlighting best practices in the realms of education and industry. Planned research also involves the evaluation of energy sustainability as a result of innovation and the role of HEIs in a broader sense, such as their connection with teaching, research and outreach. 


\section{Inovação na era digital: novo mercado de trabalho e mudanças educacionais}

\section{Resumo}

A era digital chama nossa atenção para os avanços industriais, mudanças no mercado de trabalho e no sistema educacional. Este estudo investiga tais fatores, por meio de indicadores analíticos como desempenho da força de trabalho, educação e inovação no Brasil no contexto mundial. Trata-se de uma pesquisa exploratória qualitativa, que permite refletir sobre a relação entre a força de trabalho e a educação tecnológica para mão de obra qualificada. O banco de dados utilizado incluiu dados documentais da literatura e dados de pesquisas censitárias no Brasil e no exterior. Os dados indicam que o Brasil está significativamente atrasado na indústria digital, capital humano e pesquisa; atrás de todos os outros BRICS em termos de desempenho em inovação. Cerca de 11 milhões de pessoas com idades entre 15 e 29 anos não estão trabalhando e não estão matriculadas em ensino médio, ensino superior, curso técnico ou qualificação profissional. O número de alunos de 15 a 19 anos que frequentam cursos técnicos ainda é de cerca de 9\%. A rede de institutos técnicos nacionais é essencial para a recomposição rápida de mão de obra qualificada em conexão com a indústria. A economia brasileira precisa crescer, fortalecendo a indústria digital e a pesquisa. As políticas públicas são orientadas para a educação técnica ligada à indústria e ao sucesso da Agenda Brasileira para a Indústria 4.0.

Palavras-chave: Transformação digital. Força de trabalho. Educação tecnológica. BRICS.

\section{Innovación en la era digital: nuevo mercado laboral y cambios educativos}

\section{Resumen}

La era digital llama nuestra atención sobre los avances industriales, los cambios en el mercado laboral y en el sistema educativo. Este estudio investiga dichos factores a través de indicadores analíticos como el desempeño de la fuerza laboral, la educación y la innovación en Brasil dentro del contexto mundial. Es una investigación exploratoria cualitativa que permite una reflexión sobre la relación de la fuerza laboral y la educación tecnológica para la mano de obra calificada. La base de datos utilizada incluyó datos documentales de la literatura y datos de encuestas censales en Brasil y en el extranjero. Los datos indican que Brasil se muestra significativamente retrasado en la industria digital, el capital humano y la investigación; detrás de todos los demás BRICS en términos de rendimiento de innovación. Alrededor de 11 millones de personas entre 15 y 29 años no están trabajando y no están matriculadas en una escuela secundaria, universidad, curso técnico o calificación profesional. El número de estudiantes de 15 a 19 años que asisten a cursos técnicos sigue siendo de alrededor del 9\%. La red de institutos técnicos nacionales es clave para la rápida recomposición de mano de obra calificada en relación con la industria. La economía brasileña necesita crecer fortaleciendo la industria digital y la investigación. Se aconsejan políticas públicas para la educación técnica vinculada a la industria, así como para el éxito de la Agenda Brasileña para la Industria 4.0. Palabras clave: Transformación digital. Fuerza laboral. Educación tecnológica. BRICS. 


\section{References}

AGÊNCIA IBGE. Pesquisa nacional por amostra de domicílio de 2012 a 2018 (Pnad-C): mercado de trabalho brasileiro. Rio de Janeiro, 2019. Available from: https://agenciadenoticias.ibge.gov.br/media/com_mediaibge/arquivos/81c9b274 9a7b8e5b67f9a7361f839a3d.pdf. Accessed on: 2019 July 20.

BRASIL. Ministério da Ciência, Tecnologia, Inovação e Comunicação. The Brazilian digital transformation strategy E-digitaL. Brasília, DF, 2018b.

BRASIL. Ministério da Educação. PRONATEC - Rede Federal de EPCT (PDA/MEC 2016/2018). Brasília, DF, 2018a. Available from: http://dados.gov. br/dataset/mec-pronatec-eptc. Accessed on: 2019 July 24.

CHIAPPE, A., RODRÍGUEZ, L. P. Learning analytics na educação do século XXI: uma revisão. Ensaio: Avaliação e Políticas Públicas em Educação, Rio de Janeiro, v. 25, n. 97, p. 971-991, out.-dez. 2017. https://doi.org/10.1590/s0104-40362017002501211

CONFEDERAÇÃO NACIONAL DA INDÚSTRIA - CNI. Desempenho do Brasil no índice global de inovação 2011-2016. Brasília, DF, 2016. Available from: http://www.portaldaindustria.com.br/publicacoes/2017/1/ desempenho-do-brasil-no-indice-global-de-inovacao-2011-2016/. Accessed on: 2019 July 26.

DUTTA, S.; LANVIN, B.; WUNSCH-VINCENT, S. [eds.]. The global innovation index 2016: winning with global innovation. Ithaca: Cornell University, 2016.

DYER-WITHEFORD, N. Cyber-proletariat: global labour in the digital vortex. London: Pluto, 2015.

EDUCATION AT A GLANCE. OECD Indicators. Paris: OECD Publishing, 2018.

GE REPORTS. Industry 4.0: The fourth industrial revolution and challenges for government. 2019. Available from: https://www.ge.com/reports/tag/ industry-4-0/. Accessed on: 22 July 2019.

GOMES, D. E. et al. Effectiveness of professional training offered in distance education: theoretical validation of an instrument. Ensaio: Avaliação e Políticas Públicas em Educação, Rio de Janeiro, 2019. https://doi.org/10.1590/s0104-40362019002701667 
INSIGHT REPORT. The future of jobs report 2018. Geneva: Centre for the New Economy and Society, 2018.

INSTITUTO BRASILEIRO DE GEOGRAFIA E ESTATÍSTICA - IBGE. Pesquisa Nacional por Amostra de Domicílios - PNAD: síntese de indicadores 2014. Rio de Janeiro, 2015.

INSTITUTO NACIONAL DE ESTUDOS E PESQUISAS EDUCACIONAIS ANÍSIO TEIXEIRA - INEP. Censo da Educação Superior 2017: divulgação dos principais resultados. Brasília, DF, 2018. Available from: http://portal. mec.gov.br/docman/setembro-2018-pdf/97041-apresentac-a-o-censo-superioru-ltimo/file. Accessed on: 2019 July 25.

KAGERMANN, H., WAHLSTER, W., HELBIG, J. Recommendations for implementing the strategic initiative Industrie 4.0: final report of the Industrie 4.0. [s. l.]: National Academy of Science and Engineering, 2013.

LEE, H.; KANG, P. Identifying core topics in technology and innovation management studies: a topic model approach. Journal of Technology Transfer, v. 43, n. 5, p. 1291-317, Oct. 2018. https://doi.org/10.1007/s10961-017-9561-4

MAGALHÃES, G., CATIONI, R. Professional education in Brazil: expansion for whom? Ensaio: Avaliação e Políticas Públicas em Educação, Rio de Janeiro, v. 27, n. 105, p. 732-754, 2019. https://doi.org/10.1590/s0104-40362019002701647

MALERBA, F. Innovation, industrial dynamics and industry evolution: progress and the research agendas. Revue de l'OFCE, Liège, v. 5, n. 97, p. 21-46, 2006.

MCAFEE, A., BRYNJOLFSSON, E. The second machine age: work, progress, and prosperity in a time of brilliant technologies. New York: Elsevier, 2014.

MCKINSEY GLOBAL INSTITUTE. Jobs lost, jobs gained: workforce transitions in a time of automation. New York: Mckinsey \& Company, 2017.

NAMBISAN, S., WRIGHT, M., FELDMAN, M. The digital transformation of innovation and entrepreneurship: progress, challenges and key themes. Research Policy, v. 48, n. 8, 103773, Oct. 2019. https://doi.org/10.1016/j.respol.2019.03.018

OLIVEIRA, A. D., FERREIRA, V. A., SILVA, C. M. C. S. Implications of concomitance in technical education financed by Pronatec in the Mato Grosso do Sul State education network (2012-2015). Ensaio: Avaliação e Políticas Públicas em Educação, Rio de Janeiro, v. 27, n. 103, p. 406-25, abr.jun. 2019. https://doi.org/10.1590/s0104-40362019002701715 
REITER, B. Theory and methodology of exploratory social science research. International Journal of Science and Research Methodology, [s 1.], v. 5, n. 4, p. 129-150, 2017.

ROBINSON, K., ARONICA, L. Creative schools: the grassroots revolution that's transforming education. New York: Penguin, 2016.

SCHWAB, K. The fourth industrial revolution. São Paulo: Edipro, 2016.

SILVA, J., ALMEIDA, R., STROKOVA, V. Sustaining employment and wage gains in Brazil: a skills and jobs agenda. Washington, DC: World Bank, 2015.

SJÖDIN, D. R. et al. Smart factory implementation and process innovation. Research-Technology Management, London, v. 61, n. 5, p. 22-31, 2018. https://doi.org/10.1080/08956308.2018.1471277

TAALBI, J. What drives innovation? Evidence from economic history. Research Policy, [s. l.], v. 46, n. 8, p. 1437-1453, Oct. 2017. https://doi.org/10.1016/j.respol.2017.06.007

THE IMD WORLD DIGITAL COMPETITIVENESS CENTER - IMD. The IMD World Digital Competitiveness Ranking 2018 results. Lausanne, 2018. Available from: https://www.imd.org/wcc/world-competitiveness-centerrankings/world-digital-competitiveness-rankings-2018/. Accessed on: 2019 July 20.

TORTORELLA, G. L., FETTERMAM, D. Implementation of Industry 4.0 and lean production in Brazilian manufacturing companies. International Journal of Production Research, v. 56, n. 8, p. 2975-87, 2017. https://doi.org/10.1080/00207543.2017.1391420

WINICK, E. Every study we could find on what automation will do to jobs, in one chart. There are about as many opinions as there are experts. MIT Technology Review, [s. l.], 2018. 


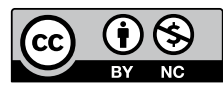

\section{Informações dos autores}

Sidney Luiz de Matos Mello: BSc., MSc., MBA, Ph.D. in Earth Sciences. Member of the Brazilian Academy of Education. Full Professor visiting the Laboratório de Tecnologia, Gestão de Negócios e Meio Ambiente from Universidade Federal Fluminense and Global Institute for Advanced Studies Researcher. Contato: smello@id.uff.br

iD https://orcid.org/0000-0003-4977-558X

Nicholas Van Erven Ludolf: BSc. and MSc. In Engineering. Researcher DSc. Student at the Laboratório de Tecnologia, Gestão de Negócios e Meio Ambiente from Universidade Federal Fluminense. Contato: nicholasuff@gmail.com

iD https://orcid.org/0000-0003-4899-1061

Osvaldo Luiz Gonçalves Quelhas: BSc. MSc in Civil Engineering and DSc in Industrial Engineering. Full Professor at Universidade Federal Fluminense; and Head of the Laboratório de Tecnologia, Gestão de Negócios e Meio Ambiente, Escola de Engenharia from the same University. Contato: osvaldoquelhas@id.uff.br

iD https://orcid.org/0000-0001-6816-1677

Marcelo Jasmim Meiriño: BSc. in Architecture, MSc. and DSc. in Engineering. Coordinator of the Professional Master's Program in Management Systems at the Laboratório de Tecnologia, Gestão de Negócios e Meio Ambiente from Universidade Federal Fluminense. Contato: marcelojm@id.uff.br

iD https://orcid.org/0000-0001-9165-2300 